Wiener, S. G., Bayart, F. E. S., FAull, K. F., a Levine, S. (1990). Behavioral and physiological responses to maternal separation in the squirrel monkey (Saimiri sciureus). Behavioral Neuroscience, 104, 108-115.

WiENER, S. G., Johnson, D. F., LeVINE, S. (1987). Influence of postnatal rearing conditions on the response of squirrel monkey infants to brief perturbations in mother-infant relationships. Physiology \& Behavior, 39, 21-26.
WINER, B. J. (1971). Statistical principles in experimental design (2nd ed.). New York: McGraw-Hill.

(Manuscript received January 24, 1989; revision accepted for publication February 3, 1992.)

\title{
International Congress of Psychology Brussels, Belgium July 19-24, 1992
}

The next International Congress of Psychology will be held in Brussels, July 19-24, 1992, under the auspices of the International Union of Psychological Science (IUPsyS).

Congress brochures may be obtained from Brussels International Conference Centre, Place des Expositions, Place de Belgique, B-1020 Brussels, Belgium (FAX 32247880 23).

\section{APA Applies for Travel Grant for Brussels Congress}

The American Psychological Association is applying for funding from the National Science Foundation, the National Institute of Mental Health, and other federal agencies to administer a block travel grant that would allow individual travel awards to be made to US participants in the scientific program of the 25th International Congress of Psychology to be held in Brussels, July 19-24, 1992. The travel grant program will be cosponsored by APA and the US National Committee of the International Union of Psychological Science.

Applicants for awards will be judged according to criteria established by the APA Committee on International Relations in Psychology.

Requests for application packets should be directed to the APA International Affairs Office (750 First Street, NE, Washington, DC 20002-4242). The deadline for receipt of completed application forms is April 1. 